\title{
OIL REVENUE AND MANUFACTURING SECTOR GROWTH IN AFRICA'S OIL-EXPORTING COUNTRIES
}

\author{
Adeleke Omolade* \\ University of KwaZulu-Natal \\ adelekeomolade@yahoo.com
}

Received: August 2013

\author{
Harold Ngalawa+ \\ University of KwaZulu-Natal \\ ngalawa@ukzn.ac.za
}

Accepted: May 2014

\begin{abstract}
The study examines the impact of oil revenue on the growth of the manufacturing sector in Africa's oil-exporting countries. It focuses on six major net oil-exporters in Africa, namely: Nigeria, Algeria, Sudan, Gabon, Cameroon and Egypt. Both static and dynamic panel data techniques are used to explore the effects of oil on the manufacturing sector of the countries between 1970 and 2010. The findings of the study show that the six countries do not exhibit significant country-specific effects, and the existence of Dutch disease is confirmed. The negative relationship between oil and manufacturing sector growth, which might be regarded as a symptom of the presence of Dutch disease, is significant in the panel dynamic model while it is not in the static model. The study also reveals that there is a dearth of capital formation in the six countries' manufacturing sectors. It is further shown that the more capital-intensive the manufacturing sector is, the less the negative effect of the oil sector's dominance. It is recommended that these countries should restructure their oil sector in such a way that proceeds from oil are largely utilised for more investment in the manufacturing sector.
\end{abstract}

Keywords

Dynamic and Static Panel Models, Manufacturing Sector growth, oil sector

\#Mr A Omolade is a doctoral candidate in the School of Accounting, Economics and Finance, University of KwaZulu-Natal, South Africa.

+Dr H Ngalawa is a senior lecturer in the School of Accounting, Economics and Finance, University of KwaZulu-Natal, South Africa. 


\section{INTRODUCTION}

In recent years the attention of development economists has shifted to unravelling the problem of economic development in countries that are well endowed with natural resources. This is based on the fact that there appears to be a consensus among development economists that many countries that are rich in natural resources display poor economic performance compared to economies endowed with fewer resources (Olomola, 2007; Bulmer-Thomas, 1994; Auty \& Evia, 2001; Sachs \& Warner, 1995). For instance, in the past four decades, members of the Organisation of Petroleum Exporting Countries (OPEC) have been experiencing stunted gross domestic product (Gylfason, 2001). In some African oil-exporting countries (AOECs) the story is the same. Nigeria, which is the largest producer of oil in Africa, fell short of the United Nation's projected GDP-per-capita by United States (US) \$495 in 2005 (Olomola, 2007), while Sudan's and Egypt's GDP per capita of US\$1,388 and US\$2,450, respectively, in 2009 were far below the GDP per capita of countries such as Morocco, US\$2,847, and Tunisia, US\$3,794, which are not oilexporting countries (see International Monetary Fund (IMF), 2010).

Both the World Bank and International Monetary Fund have emphasised the need for the oilexporting countries in Africa to embrace diversification. They have described this as a panacea to their economic problems (World Bank, 2004; IMF, 2008). The manufacturing sector has been tipped as a major sector that can help in the diversification process. This sector has been described as a major catalyst that can boost local output of the real sector of the AOECs' economies. For instance, among 65 countries that can be classified as rich in natural resources, only Botswana, Indonesia, Malaysia and Thailand had long-term investment exceeding $25 \%$ of their GDP between 1970 and 1998 and also recorded GNP per-capita growth exceeding $4 \%$ in a year (Olomola, 2007; Gylfason, 2001). The major reason for the success of these economies was their ability to effectively diversify through accelerated growth in domestic output, which was made possible through a vibrant manufacturing sector (Olomola, 2007).

However, the manufacturing sector in the A0हCs has generated some concerns. In Nigeria, for instance, the contribution of the manufacturing sector to GDP has been dwindling over the years from $2.6 \%$ in 1994 to $1.4 \%$ in $1996,1.02 \%$ in 1998 and $0.5 \%$ in 2000 . In Algeria the manufacturing sector's contribution to GDP fell from $6.6 \%$ in 2003 to $5.2 \%$ in 2005 and $4.9 \%$ in 2006; in Libya it fell from $4.2 \%$ in 2003 to $3.5 \%$ in 2006; while in Angola it fell from $3.4 \%$ in 2003 to $2.2 \%$ in 2006 (League of Arab States Reports, 2009; Majid, 2006). Based on the foregoing, it appears that the manufacturing sector of the AOECs has not been performing well over this period.

In his bid to examine the impact of oil rents on the growth of oil-exporting economies in Africa, Olomola (2007) described the fall in domestic output as a major growth problem in A0ECs and specifically called for an assessment of the effect of oil on the non-oil production sector. He described this assessment as a way of unravelling the problem of economy diversification that has refused to see the light of day in many AOECs. However, the manufacturing sector has been described as a major non-oil sector that can boost domestic output (IMF, 2005). Consequently, there is a need to assess the impact of oil on this important sector, which is also described by Kayode (2000) as 'the engine room of the industrial sector in any economy'. 


\section{BACKGROUND}

Over the years different controversies have surrounded the relationship between oil rents and other sectors of the economy of an oil-producing country. For instance, in their studies of Arab oil-producing countries, Lay and Mahmoud (2005), Beblawi and Luciani (1987) and Karl (1997) argued that the presence of oil in Arab countries such as Libya, Algeria, Egypt, Iraq, Syria and Saudi Arabia has constituted a serious impediment to the growth of the manufacturing sector in these countries. They based their arguments on the phenomenon of Dutch disease and resource curse. On the other hand, Stauffer (1984), Jabber (1997), Majid (2006) and Amuzegar (2001) have argued that many oil-exporting countries have utilised the forward-linkage effect of the oil industry to improve the growth of their manufacturing sectors. According to Majid (2006), the contribution of oil in some Arab oil-exporting countries in recent times is evident in the tremendous growth witnessed in the petrochemical industry, which was initially based on natural gas and its liquid form. He further stated that after the first oil-price boom, the development of the industrial sector, especially the petrochemical companies, was accelerated as a result of more liberal government policies that created an enabling climate for effective utilisation of oil as a catalyst for aiding diversification in industries. In the Arab oil-exporting countries, the contribution of the oil sector to the manufacturing sector, in terms of value added, increased from 25 billion US dollars in 1990 to 54 billion US dollars in 2004 (OPEC Fund for Industrial Development (OFID), 2006.)

However, different studies have been conducted on the effect of oil on the growth of some oilproducing economies. Olomola (2007) focused on the effect of oil wealth on the growth of Africa's oil-exporting economies. Majid (2006) examined the contribution of the oil sector to the economic development of Arab countries. In 2009 the League of Arab States and the United Nations Economic and Social Commission for Western Asia examined how industrial development can be sustained in Arab countries (League of Arab States Reports, 2009). Despite such studies, it appears that the exact relationship that exists between oil rents and the manufacturing sector is yet to be explored. The controversy explained above is yet to be empirically examined in the light of these studies to determine which of the two sides is correct. Therefore, to provide wider policy alternatives that can serve as a catalyst for boosting the growth of the AOECs' manufacturing sector, this study, using panel data analysis, undertakes an empirical assessment of major AOECs in a bid to examine the impact of oil revenue on manufacturing sector growth. The study also investigates the presence of Dutch disease in the AOECs and assesses the nature of the relationship between manufacturing sector growth and other macroeconomic variables such as exchange rates and capital formation, among others.

\section{METHODOLOGY AND DATA}

There are two divergent views regarding the impact of oil revenue on the growth of the manufacturing sector in AOECs. While some believe that the presence of oil in these countries contributes to the growth of their manufacturing sectors, others are of the opinion that the presence of oil is a setback for their manufacturing sectors. Consequently, to examine the impact of oil on the development of the manufacturing sector in A0ECs, a study of six major net oil-exporting countries in Africa, namely Nigeria, Cameroon, Gabon (Sub-Saharan Africa), Egypt, Algeria, and Sudan (non-Sub-Saharan Africa), was carried out using pooled data analysis. Initially this study set out to cover all oil-exporting countries in Africa. However, due 
to the fact that not all of them have dominant oil sectors, we focus on six net oil-exporters only. Our model follows the endogenous growth model of Barro and Lee (1993) with public good. According to them, public expenditure makes private production more profitable. Barro's model is expressed thus:

$$
y=A k^{1-\propto} g^{\propto}
$$

where $y$ is subject to diminishing returns to capital $(k)$ and $g$ is a control variable constituting electricity, exchange rate and per capita income. The individual firm takes $g$ as fixed or independent of its decision about $k$. Fedderke (2003) identified the nature of the marginal product of capital (mpk) as the reason why some countries with high per capita output experience lower growth rates than the ones with lower per capital output. That is, if

$$
y_{x}=A k_{x}^{(1-\alpha)_{x}} g_{x}^{\alpha_{x}}
$$

where $y_{x}$ is the per capita output growth of country $x$ with high per capita output; and

$$
y_{z}=A k_{z}^{(1-\alpha)_{z}} g_{z}^{\alpha_{z}}
$$

where $y_{z}$ is the per capita output growth of country $z$ with lower per capita output, then

$$
\Delta y_{z}>\Delta y_{x}
$$

where both $\Delta y_{x}$ and $\Delta y_{z}$, which are the changes in the per capita output growth of the countries, represent the growth rate of per capita output in country $x$ and $z$, respectively. For the condition in equation (4) to have taken place, $m p k$ must be a constant and not associated with per capita output. Fedderke (2003) attributes the constant nature of the mpk to the spill-over effect of knowledge in the process of capital stock accumulation. This means that knowledge has the characteristics of a public good. That is:

$$
k_{t}=\vartheta \emptyset_{t}
$$

Equation (5) shows that capital stock $k$ at time $t$ depends on knowledge $\phi$ at time $t$ such that $\frac{d k_{t}}{d \emptyset_{t}}=\vartheta>0$.This means that knowledge is seen as investing in a process that increases capital stock in all economies. According to Fedderke (2003), investors might not have the power to internalise all the benefits of knowledge. At least some of it still leaked out to the benefit of the whole economy. This simply means that the spill-over effect of knowledge $\phi$ is non-excludable. Consequently, investors will not want to invest in capital to the point where:

$$
\operatorname{smpk}=\operatorname{smpc}(\text { spill-over effect })
$$

where smpk is the social marginal product of capital and $s m p c$ is the social marginal cost. Investors will rather stop investing in capital when:

$$
p m p k=p m c
$$

thus avoiding the spill-over effect. $p m p k$ is the private marginal product of capital and $p m c$ is the private marginal cost. The implication of equation (7) is that:

$$
\text { smpk }>\text { smc }
$$


This is because once investors set the private marginal product of capital equal to the private marginal cost, the cost of knowledge becomes higher than its cost. Consequently, a more drastic measure will be taken to prevent the spill-over effect by investors.

This situation might be detrimental to the growth of the economy as a whole. At this juncture, government intervention comes in by aiding production through subsidising major inputs in the production process (Fedderke, 2003). Therefore, equation (8) can be rewritten as follows:

$$
y=A k^{1-\propto-\infty} g^{\propto} \lambda^{\infty}
$$

where $\lambda^{\infty}$ is the additional input subsidised to aid production. This is to reduce the higher cost of production resulting from setting $p m p k$ to $p m c$. This will enable investors to relax their drastic measures to internalise the benefits of knowledge, and the spill-over effects can benefit other sectors of the economy.

Our model follows equation (9) and $\lambda^{\infty}$ is viewed as oil, which is heavily subsidised in many $A 0 \varepsilon C s$. Consequently, our model is stated thus:

$$
y=A k^{1-\propto-\infty} o i l^{\infty} g^{\alpha}
$$

Taking logs of the equation it becomes:

$$
\log y_{i, t}=\log A+\beta \log k_{i, t}+\infty \log O i_{i, t}+\propto \log g_{i, t}+\varepsilon_{i, t}
$$

where $y_{i, t}$ is the manufacturing sector output growth rate of county $i$ at time $t$, A is the intercept, $k$ is capital, $\beta$ is the elasticity of capital and it is equal to $\beta=1-\alpha-\infty$, oil is oil revenue and $g_{i, t}$ is a control variable that comprises electricity, exchange rate and per capita income. $\varepsilon_{i, t}$ is the stochastic variable.

\subsection{Definition of variables}

All variables measured in monetary terms are in constant US dollars. Manufacturing sector growth $(y)$ is the dependent variable. It is measured by annual growth rate for manufacturing value added.

\subsubsection{Explanatory variables}

Capital $(K)$ is an endogenous variable in the model. It is measured by gross capital formation. It consists of outlays on additions to the fixed assets of the economy plus net changes in the level of inventories.

Oil Revenue (oil) is our real variable of interest. It is measured by the value of fuel exports (\% of merchandise exports).These fuels comprise premium motor spirit (PMS), dual purpose kerosene (DPK) and automotive gas oil (AGO).

\subsubsection{Control variables}

The control variables $(g)$ are strictly exogenous covariates. They are: per capita income (pci), real exchange rate (exr), and electricity generation (ele). Per capita income is captured by GDP per capita based on purchasing power parity (PPP). PPP GDP is gross domestic product converted to international dollars using purchasing power parity rates. The real exchange rate is the 
official exchange rate (local currency unit (LCU) per US\$, period average). It is the exchange rate determined by national authorities or determined in the legally sanctioned exchange market. It is calculated as an annual average based on monthly averages (LCU relative to the US dollar). The electricity generation is measured by electricity production, which is also measured at the terminals of all alternator sets in a station. In addition to hydropower and nuclear power generation, it covers generation by geothermal, solar, wind, and tide and wave energy, as well as that from combustible renewable and waste. Production includes the output of electricity plants that are designed to produce electricity only, as well as that of combined heat and power plants.

\subsection{Estimation technique}

According to Gujarati (2007), if T, which is the number of time series data, is large and the number of cross-sectional units is small, the fixed effect is more appropriate. This is referred to as long panel. According to Toress (2010), the fixed effects, unlike the ordinary least squares, considers heterogeneity across groups and time, hence the estimates from the fixed effects model are more efficient. Hauser (2010) argues that the assumption that individual intercepts must be uncorrelated with the error term before random effects can be used is usually violated in long panel, thus making the random effects model inconsistent. According to him, one of the immediate solutions is to use fixed effects. However, Gujarati (2007) sums up all these views about the choice of fixed or random effects by stressing that, if the panel is long (i.e. the number of time series $\mathrm{T}$ is larger than the number of cross-sectional units $\mathrm{N}$ ) there is likely to be little difference in the values of the parameters generated by both fixed and random effects. Therefore, the choice is based on computational convenience and consequently he advised that fixed effects are preferable in this circumstance. Since our data is from 1970 to 2010 (i.e. 40 years) and the number of countries under consideration is only six, the choice of the fixed effects model appears appropriate.

The fixed effects equation in its original form is presented as follows:

$$
y_{i t}=\beta_{1}+\beta_{2} x_{2 i t}+\beta_{3} x_{3 i t}+\beta_{4} x_{4 i t}+\mu_{i t}
$$

where $\beta_{1}$ is the intercept, while $\beta_{2}$ to $\beta_{4}$ represent the slopes or the parameter estimates of each of the three explanatory variables used in our model. $x_{2 i t}$ to $x_{4 i t}$ are explanatory variables for each of the six countries (cross sectional units) at time $t$.

The index $i$ stands for the $t^{\text {th }}$ cross-sectional unit (country), and $\mathrm{t}$ is a year counter. That is $i=1$, $2,3,4,5,6$ and $t=1,2 \ldots 40$. The pooled regression analysis can be done by estimating equation (12). According to Gujarati (2007), it is necessary to explore the specific effects of the crosssectional units. This takes us to the fixed effects least-square dummy variable (LSDV) approach. LSDV has been described as a way of accounting for the specific effects of the countries on $y$. This is done by allowing the intercept to vary across the cross-sectional units and leading to equation (13).

$$
y_{i t}=\beta_{1 i}+\beta_{2} x_{2 i t}+\beta_{3} x_{3 i t}+\beta_{4} x_{4 i t}+\mu_{i t}
$$

The subscript $i$ added to $\beta$ suggests that the intercepts of the individual countries may be different, which may be attributed to the country's system of administration, leadership style and administrative philosophy. The fixed effects or the LSDV use the different intercept dummies to measure the specific effects of the cross-sectional units. Accordingly, equation (13) can be rewritten as: 


$$
y_{i t}=\propto_{1}+\propto_{j} \sum_{j=2}^{6} D_{j i}+\beta_{k} \sum_{k=2}^{3} \beta_{k} x_{k i t}+\mu_{i t}
$$

Equation (14) is also known as the least-square dummy variable model.

Gujarati (2007) further states that there is a possibility of a multicollinearity problem in the fixed effects LSDV model due to the addition of many dummy variables, especially in small samples. Again, because of the assumption of strict exogeneity of LSDV, the fixed effects model may possibly have an endogeneity problem. This is the situation where the random variable is possibly correlated with the regressors $x_{i t}$ thereby leading to inconsistent and biased estimators.

To improve the performance of the estimators, we explored the dynamic panel data approach popularised by Arellano and Bond (1991). According to Franz (2009), when a static specification of the fixed effects model is joined with autoregressive coefficients, which is the lagged value of the dependent variable, it allows feedback flowing from the past or current shocks to the current value of the dependent variable. This method of specification is known as the generalised method of moments (GMM). The dynamic specification takes away the temporal autocorrelation in the residuals and prevents running a spurious regression, which may lead to inconsistent estimators. The GMM model is specified thus:

$$
y_{i t}=\beta_{1}+\rho y_{i t-1}+\beta_{2} x_{2 i t}+\beta_{3} x_{3 i t}+\beta_{4} x_{4 i t}+\mu_{i t}
$$

Equation (15) is the modified form of the fixed effects model in equation (14) with the addition of the lagged value of the dependent variable.

Taking the first difference of equation (15), we obtain equation (16) as follows:

$$
\Delta y_{i t}=\beta_{1}+\rho \Delta y_{i t-1}+\beta_{2} \Delta x_{2 i t}+\beta_{3} \Delta x_{3 i t}+\Delta \psi_{i t}
$$

Avoiding possible correlation between $y_{i t-1}$ and $\psi_{i t}$ necessitates the use of an instrumental variable that will not be correlated with both, and through matrix transposition of the explanatory variable, instrumental variable $Z^{\prime}$ is obtained. Equation (16) is multiplied in vector form by $Z^{\prime}$ leading to:

$$
Z^{\prime} \Delta y_{i t}=Z^{\prime}\left(\Delta y_{-1}\right) \rho+Z^{\prime}(x) \beta_{i t}+Z^{\prime} \Delta \psi_{i t}
$$

Estimating equation (17) using the generalised least square (GLS) yields one step consistent GMM estimators. However, additional input to the approach used by Arellano and Bond (1991) evolved over the years and was developed by Blundell and Bond (1998), and is referred to as system-GMM. There is not much difference between this approach and GMM except that systemGMM exercises more caution in the use of the instrumental variables. It was developed to tackle the problem of possible weak instrumental variables, which may occur in GMM. Therefore, the SYS-GMM is expected to yield more consistent and efficient parameter estimates. This will be explored in our dynamic panel data analysis.

\subsection{Data}

Data on manufacturing growth rate, capital stock proxied by gross capital formation of each AOEC, per capita income, oil revenue and electricity generation were sourced from World Bank Tables 2012 edition. Data on exchange rates was sourced from Penn World Table (PWT) 6.1. 


\section{EMPIRICAL RESULTS}

\subsection{Descriptive statistics of the variables}

TABLE 1 shows the descriptive statistics of the variables for the six countries under study.

TABLE 1: Descriptive statistics

\begin{tabular}{lccccc}
\hline \multicolumn{1}{c}{ Variables } & Observations & Mean & $\begin{array}{l}\text { Standard } \\
\text { Deviation }\end{array}$ & Minimum & Maximum \\
\hline $\begin{array}{l}\text { Manufacturing } \\
\text { growth rate }\end{array}$ & 246 & 5.14711 & 9.601761 & -26.58229 & 47.8 \\
\hline $\begin{array}{l}\text { Per capita income } \\
\text { Capital }\end{array}$ & 246 & 7.021713 & 2.248785 & -1.547871 & 9.610885 \\
\hline $\begin{array}{l}\text { Oil revenue } \\
\text { Exchange rate }\end{array}$ & 246 & 20.19376 & 4.445465 & 7.40117 & 24.79918 \\
\hline $\begin{array}{l}\text { Electricity } \\
\text { generation rate }\end{array}$ & 246 & 3.41651 & 2.031008 & -9.124365 & 4.601729 \\
\hline
\end{tabular}

Source: Authors' calculations

All variables appear in log form to show their elasticities, except manufacturing sector growth rate and real exchange rate.

The mean represents the average value of the data set. Attention is given to manufacturing growth rate and oil revenue because they are our core variables of interest. The mean value of the manufacturing growth rate is 5.14711. The value shows that the mean lies at the lower end of the distribution. The majority of our data values on manufacturing growth rate for all the countries must be concentrated at the lower end. The highest manufacturing growth rate is 34.6, while the lowest is -2.4 . This means that the mean drifts toward the lower end, as earlier stated. Therefore, on average it appears that the manufacturing growth rates of the AOECs are relatively low. Comparatively, the mean value of 3.41651 of oil revenue falls at the middle level of the distribution, which is an indication that oil revenue growth rate is relatively moderate at a higher level than manufacturing growth rate for all the AOECs.

The table shows that the standard deviation of manufacturing growth rate is 9.60176 , while that of oil revenue is 2.031008 . This is an indication that the data on manufacturing growth rate shows a more dispersed distribution. That is, this data appears to have a larger variance across the six countries than the data on oil. This means that the patterns of growth of the manufacturing sector of these countries have been somewhat unstable.

The description of manufacturing sector growth rate (mgr) and oil revenue (oil) is again presented in FIGURE 1. The figure describes the characteristics of the two variables across the six countries. 


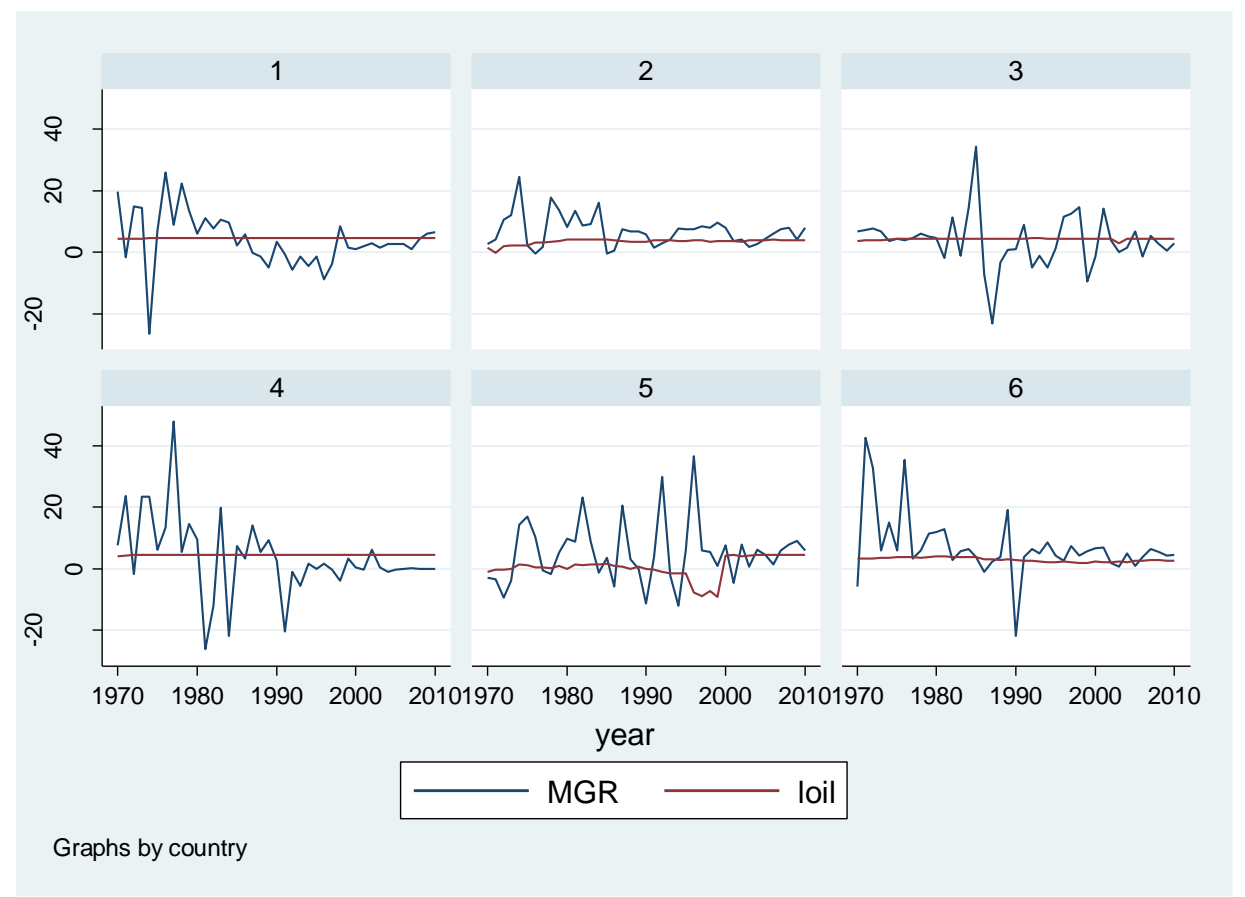

FIGURE 1: Manufacturing sector growth rate (mgr) and oil revenue (oil ) in A0ECs

\section{Source: Authors'calculations}

1 = Algeria; 2 = Egypt; 3 = Gabon; 4 = Nigeria; 5 = Sudan

The graphs simply corroborate the result of the descriptive analysis of the data shown in TABLE 1 . That is, the pattern of manufacturing sector growth (mgr) shows more variation through the undulating line graph than oil revenue in the six $A 0 E C s$, which show almost a straight line graph across the countries. While the oil revenue line graph follows a non-negative movement fairly above the origin for most of the countries, the manufacturing sector growth has been very unstable and undulating around the origin for all the six countries. The similarities in the patterns of distribution across the six countries are an indication that the findings can be generalised for all other African oil-exporting countries not covered in our panel data analysis.

TABLE 2 shows the correlation and covariance nature of the variables used in our model. The variables exhibit different forms of relationship with one another. However, very important to our discussion is the correlation between the oil revenue and the manufacturing sector growth rate, which is -0.0879 . This is an interesting result, as it is shown that they are likely to have an inverse relationship. However, the value is very low, which is an indication of a weak negative relationship. Generally, apart from capital formation, all other independent variables show a negative relationship with the manufacturing sector growth of the AOECs. 
TABLE 2: Correlation matrix

\begin{tabular}{|c|c|c|c|c|c|c|}
\hline & $\begin{array}{l}\text { Manufacturing } \\
\text { growth rate }\end{array}$ & $\begin{array}{c}\text { Per } \\
\text { capita } \\
\text { income }\end{array}$ & Capital & $\begin{array}{l}\text { Oil } \\
\text { revenue }\end{array}$ & $\begin{array}{c}\text { Exchange } \\
\text { rate }\end{array}$ & $\begin{array}{c}\text { Electricity } \\
\text { generation } \\
\text { rate }\end{array}$ \\
\hline $\begin{array}{l}\text { Manufacturing } \\
\text { growth rate }\end{array}$ & 1.0000 & & & & & \\
\hline Per capita income & -0.1843 & 1.0000 & & & & \\
\hline Capital & 0.0210 & 0.1436 & 1.0000 & & & \\
\hline Oil revenue & -0.0879 & 0.1919 & -0.1571 & 1.0000 & & \\
\hline Exchange rate & -0.0894 & 0.4251 & 0.0348 & 0.2291 & 1.0000 & \\
\hline $\begin{array}{l}\text { Electricity } \\
\text { generation rate }\end{array}$ & -0.0925 & 0.1939 & 0.0750 & 0.2431 & -0.4048 & 1.0000 \\
\hline
\end{tabular}

Source: Authors' calculations

\subsection{Estimation results}

The idea of using panel data analysis is justified in that it takes care of the unobserved heterogeneity. Therefore, to be able to explain in detail the causal-effect relationship between the dependent and the independent variables and to study the within variations, we use the error-components. This includes fixed effects and random effects. However, based on the nature of our data, which contains forty time series and six cross-sectional variables, as explained in the methodology, we use only the fixed effects analysis. This is explored in the form of within variation and least squares dummy variables (LSDV).

TABLE 3: Fixed effects (within variation regression) estimation results for manufacturing sector growth rate

\begin{tabular}{lccc}
\hline \multicolumn{1}{c}{ Variables } & Coefficient & Standard error & t value \\
Constant & $99.38583 \star \star \star$ & 22.19101 & 4.48 \\
\hline Per capita income & 0.4735527 & 0.4819848 & 0.98 \\
Capital & 0.3638414 & 0.9524375 & 0.38 \\
Oil revenue & -0.0285611 & 0.409897 & -0.07 \\
$\begin{array}{l}\text { Exchange rate } \\
\begin{array}{l}\text { Electricity generation } \\
\text { rate }\end{array}\end{array}$ & 0.0168206 & 0.009636 & 1.74 \\
\hline
\end{tabular}

Source: Authors' calculations

Note: Standard errors in parentheses

$\mathrm{R}^{2}=0.0857$ (within) $\mathrm{R}=0.0010$ (overall) $\mathrm{F}(5,230)=4.31 * \star \star$

* statistical significance at $10 \% \star \star$ statistical significance at $5 \% . \star \star \star$ statistical significance at $1 \%$ 
TABLE 3 shows the fixed effect results. From the table, it is clear that there is an inverse relationship between manufacturing sector growth in the AOECs and their oil revenues. The result corroborates our descriptive analysis in the correlation matrix presented in TABLE 2, where we found that the coefficient of correlation between the two is negative. In one sense this supports the evidence of Dutch disease in these countries, because the inverse relationship can be termed as a situation where the oil output is growing and the manufacturing sector growth is falling. However, the coefficient is not statistically significant. Again, the overall R-square is very low. The regressors explained about $0.1 \%$ variation in manufacturing sector growth. The within variation is nonetheless higher, explaining about $8.6 \%$ variation. The entire model is statistically significant at a $5 \%$ level (where the $\mathrm{F}$ value is 4.32 and the probability value is 0.0009).

To be able to demonstrate the specific effects of the cross-sectional units, we also compute the fixed effect LSDV. The purpose of this is to examine if individual-country impact is likely to have any influence on our results. Despite the fact that Figure 1 shows a similar pattern for both manufacturing sector growth and oil revenue, there may still be a difference in the impact analysis of these variables. This is done by allowing the intercept to vary from country to country. The result of the fixed effects LSDV is presented in Table 4.

Table 4: Fixed effects (LSDV) estimation results for manufacturing sector growth rate

\begin{tabular}{lccc}
\hline Variables & Coefficient & Standard error & $t$-value \\
\hline Constant & $101.4067 \star \star \star$ & 22.82078 & 4.44 \\
Dum 2 & $8.907043 \star \star$ & 2.999682 & 2.97 \\
Dum 3 & $-19.43958 \star \star$ & 6.15398 & -3.16 \\
Dum 4 & 3.684153 & 11.99062 & 0.31 \\
Dum 5 & $-6.937674 \star \star$ & 3.100352 & -2.24 \\
Dum 6 & 1.925871 & 2.673398 & 0.72 \\
Per capita income & 0.4735527 & 0.4819848 & 0.98 \\
Capital & 0.3638414 & 0.9524375 & 0.38 \\
Oil revenue & -0.0285611 & 0.409897 & -0.07 \\
\hline Exchange rate & 0.0168206 & 0.0096936 & 1.74 \\
Electricity generation & 4.729151 & 1.472804 & 3.21 \\
\hline rate & & & \\
\hline
\end{tabular}

Source: Authors' calculations

Note: Standard error in parenthesis

$\mathrm{R}^{2}=0.1149$ (overall) $\mathrm{F}(5,230)=2.84 * \star$

** statistical significance at $5 \%$.*** statistical significance at $1 \%$.

The fixed effects LSDV results presented in TABLE 4 show some important revelations when compared to the previous results in TABLE 3. As earlier indicated, the use of the fixed effects LSDV is justified by the need to examine the specific effects of the countries on our results by allowing the intercept to vary across the countries. Again, the bias of inconsistent estimator 
varnishes when $T$ is large and $N$ is small in the LSDV model. In our model $T=41$ and $N=6$. The dummies represent the individual intercepts of the six countries. Their values are shown in the table together with their $t$ values and the probability. The results show that three of the intercepts are individually statistically significant. That is, the intercept values of three out of six countries are statistically different from zero. This shows that there is a relative countryspecific effect in our model, which may be attributed to the individual country's system of administration, leadership style and administrative philosophy (Olomola, 2007, Gujarati, 2007).

The LSDV fixed effects results also show that the parameter estimate of oil is negative. This is consistent with earlier findings in the fixed effects within group estimation. It further confirms the existence of Dutch disease problems in the AOECs. The value of the R-square in the LSDV is higher compared to the fixed effects within variation in TABLE 3. The F-statistic rises significantly, confirming that the fixed effect LSDV model is more significant. According to the results, none of the explanatory variables is statistically significant at conventional levels. For instance, the elasticity of capital formation in the AOECs is positive, indicating a direct relationship between capital formation and the manufacturing sector growth rate. Although this is normal and conforms to the a priori expectation, it is not statistically significant. This further justifies the inverse relationship between the oil sector growth as measured by the revenue from oil and the manufacturing sector growth of the A0ECs. This is evident in the huge investment in the oil sector of these economies, since all other sectors, including the manufacturing sector, appear to have been neglected.

The per capita income elasticity is also positive but not statistically significant, meaning that the per capita GDP of the AOECs has no significant impact on the manufacturing sector growth. This might be the major reason why the contribution of the manufacturing sector to the GDP of these countries is very low. The coefficient of the exchange rate is also not significant, but it is positive, indicating a direct relationship between manufacturing sector growth and the exchange rate. A probable explanation is that as the exchange rate rises manufacturing sector growth is likely to rise in the AOECs and vice versa.

The elasticity of electricity is also positive but also not statistically significant. The nonsignificance of the electricity coefficient simply means that, in the AOECs, the quantity of electricity generation is still not enough to ensure a sustainable growth in the manufacturing sector. For instance, Nigeria, which is part of the A0ECs under investigation, has been experiencing an erratic supply of electricity for decades, and this has been affecting the manufacturing sector of the country adversely. Many manufacturing firms in the country rely on gas-powered generators in their production processes, and this has contributed significantly to the increase in the cost of production of these firms. Recently, some giant manufacturing firms closed down their operations in Nigeria and relocated to neighbouring Ghana due to the high cost of production caused by excessive expenditure on gas and diesel. Specifically, in 2009, PZ Pharmaceuticals, Unilever Nigeria PLC and United Africa Company (UAC) relocated substantial parts of their companies to neighbouring Ghana. They blamed the development on the deplorable state of infrastructural facilities in the country, especially energy (see Nigeria Village Square (NVS) forum 2009 report).

Finally, the fixed effects LSDV results are capable of yielding a consistent estimator when the T is large and $\mathrm{N}$ is small. According to Arellano and Bond (1991), to obtain an efficient estimator in panel models, the dynamic panel model is preferred. Consequently, we proceeded to conduct a robustness check for our model using both the generalised method of moments (GMM) and the system generalised method of moments (SYS-GMM) estimation by Arellano and Bond (1991) and 
Blundell and Bond (1998), respectively. The usage of the two is justified by the need to study the consistency of our results in dynamic panel models, having found out that the results were consistent in the two previous fixed effects models.

\subsubsection{GMM and SYS-GMM estimation for manufacturing sector growth in AOECs}

Arellano and Bond (1991) argued that fixed effects LSDV might be inefficient, hence the need to exploit the orthogonality conditions that exist between the lagged values of the dependent variable and the disturbance term through the use of an additional instrument in the model. This approach is called the generalised method of moments (GMM). This was modified by Blundell and Bond (1998) due to the fact that the assumption of strict exogeneity is more relaxed and is capable of yielding a more efficient estimator (Roodman, 2006).

Table 5: The GMM and SYS-GMM estimation results for manufacturing sector growth rate (mgr)

\begin{tabular}{|c|c|c|c|c|c|}
\hline $\begin{array}{c}\text { Dynamic Panel } \\
\text { Data Analysis }\end{array}$ & Variables & Coefficient & Standard Error & $Z$ & Probability z \\
\hline \multirow[t]{6}{*}{ GMM } & $\begin{array}{l}\text { Manufacturing } \\
\text { growth rate Ll }\end{array}$ & -0.0202367 & 0.0645919 & -0.31 & 0.754 \\
\hline & Per capita income & 0.4383802 & 0.5013518 & 0.87 & 0.382 \\
\hline & Capital & 0.4004976 & 0.9312599 & 0.43 & 0.667 \\
\hline & Oil revenue & -0.2915597 & 0.3998965 & -0.73 & 0.466 \\
\hline & Exchange rate & $0.0197917 \star \star$ & 0.0098749 & 2.00 & 0.045 \\
\hline & $\begin{array}{l}\text { Electricity } \\
\text { generation rate }\end{array}$ & 5.089826 & 1.552222 & -3.28 & 0.091 \\
\hline Wald chi2(6) & $=18.78$, Prob $>$ chi2 & $=0.0045$ & & & \\
\hline \multirow[t]{6}{*}{ SYS-GMM } & $\begin{array}{l}\text { Manufacturing } \\
\text { growth rate LI }\end{array}$ & 0.0778381 & 0.0507784 & 1.53 & 0.125 \\
\hline & Per capita income & -0.3366477 & 0.392417 & -0.86 & 0.391 \\
\hline & Capital & 0.3981301 & 0.2572094 & 1.55 & 0.122 \\
\hline & Oil revenue & $-0.7079312 \star \star$ & 0.3125724 & -2.26 & 0.024 \\
\hline & Exchange rate & 0.0001853 & 0.0062226 & 0.03 & 0.976 \\
\hline & $\begin{array}{l}\text { Electricity } \\
\text { generation rate }\end{array}$ & 0.0465988 & 0.259019 & -0.18 & 0.857 \\
\hline Wald chi2(6) & Prob>chi2 & $=0.018$ & & & \\
\hline
\end{tabular}

Source: Authors' calculations

** statistical significance at $5 \% . * *$ statistical significance at $1 \%$

This approach is a form of dynamic panel modelling that limits the tendency of having a spurious regression, which may lead to wrong inferences, something common in static models. The results of the dynamic panel models are presented in TABLE 5 . 
The results of the GMM and SYS-GMM are shown in TABLE 5. This is another confirmation of our inferences from the previous estimated models. It is clearly shown that there is consistency in our results regarding the different models estimated, i.e. from the fixed effects within group estimation to the fixed effects LSDV and dynamic models, which comprise both the GMM and SYS-GMM. All the coefficients signs are almost the same for the two dynamic models. For instance, they both show that the coefficient of oil is negative, which is the same as what we obtained from our previous fixed effects models. The two dynamic panel models are statistically significant at $5 \%$ level with Wald Chi2 probability value of 0.0045 and 0.0181 for GMM and SYSGMM, respectively.

The only difference in the results obtained from all the models is in the significance of the parameter estimates. The SYS-GMM results, which according to the literature produce the most reliable parameter estimates, confirm the statistical significance of the oil parameter coefficient. That is, the coefficient of oil is negative and statistically significant, showing that oil revenue, which can be seen as a measure of oil sector growth, has a significant negative impact on the manufacturing sector of the AOECs. Specifically, the result indicates that a unit rise in the oil revenue (oil sector growth) will lead to about a $29 \%$ fall in the growth of the manufacturing sector of the AOECs.

We conclude that there is an inverse relationship between oil revenue and manufacturing sector growth of the AOECs. In terms of impact analysis, we conclude that oil revenue, which is a measure of the growth in the oil sector, has a significant negative impact on manufacturing sector growth in the AOECs.

\section{DISCUSSION AND CONCLUSION}

We draw some important inferences from the study. The analysis shows that the six A0ECs used in our study did not exhibit much difference in the relationship between their oil sector and the manufacturing sector. This is confirmed from the descriptive statistics, which show that there is no overwhelmingly significant country-specific effect on the nature of both oil revenue and manufacturing sectors in the six countries. The fixed effects LSDV results also do not show absolute support for country-specific effects. The implication of this result is that the findings can be generalised to other oil-exporting countries in Africa not included in the study.

The existence of Dutch disease is observed in the negative relationship between the oil sector and the manufacturing sector of the AOECs. This is supported by all models. The inference supports the view of many authors who have used different variables and analyses to confirm the existence of Dutch disease in oil-exporting countries (Égert \& Leonard, 2007; Olomola, 2007; Ismail, 2010; and Majid, 2006).

The study confirms that the negative impact of the oil sector on the manufacturing sector of the A0ECs is more significant in the dynamic panel model than the static models. The finding is at variance with Mehrara, Sadr and Farhani (2008), who concluded that oil revenue does not have a significant negative impact on the non-oil manufacturing sector. Though they confirm a negative relationship, they concluded that it is not significant. It can now be seen that their conclusion might be due to the static model they used. Our dynamic model, specifically the SYSGMM model, which is capable of showing a more reliable result when compared with the static models, indicates that oil has a negative significant impact on the manufacturing sector of the AOECs. 
Another important inference from the study is the existence of a positive relationship between the exchange rate and manufacturing sector growth. A similar result was obtained by Égert and Leonard (2007) in their study of the oil-rich Republic of Kazakhstan. The coefficient of the exchange rate is not significant for the AOECs' manufacturing growth rate, but a direct relationship is confirmed.

The stunted growth of capital formation in the manufacturing sector of AOECs is revealed in our study. Both the static and dynamic panel models show that capital does not have a significant impact on the manufacturing sector of the AOECs. This means that the manufacturing sectors are less capital intensive. The implication of this is shown in the work of Ismail (2010), where he concluded that manufacturing sectors that are more capital intensive are less affected by the adverse effect of oil in some oil-exporting countries. This means that it can be inferred that the more capital intensive the manufacturing sector is, the more insulated it becomes to shocks from the oil sector.

Finally, the non-significance of the estimator of electricity generation in most of our models shows further support for the low investment in the manufacturing sector of the A0ECs. This situation is evident in some oil-exporting countries such as Nigeria, where manufacturing firms are closing down and relocating to neighbouring countries where there is a more stable supply of electricity. Many of these firms take this step to reduce the high marginal cost of production resulting from the need to find alternative sources of energy.

It can be concluded that there is Dutch disease in the AOECs, as shown by the negative relationship between the oil revenue and the manufacturing sector growth. Thus, the study contributes to the growing consensus on the existence of Dutch disease in many oil-rich nations in the world. It is also discovered that the growth of the oil sector has a significant negative impact on the manufacturing sector of the AOECs. The implication of this is that, apart from addressing policies to improve the manufacturing sector through diversification and investment policy, among others, effort must be made to plough back the revenue realised in the oil sector to the real sector of the economy. Utilising a substantial part of oil revenue for the development of the manufacturing sector may likely cause the oil sector to start exhibiting positive and meaningful effects on the manufacturing sector of the AOECs.

The study confirms that the exchange rate demonstrates a positive relationship with the manufacturing sector growth of AOECs. This corroborates the findings of Égert and Leonard (2007), among others, who also concluded from their studies that the exchange rate has a direct relationship with the manufacturing sector growth of the oil-rich Republic of Kazakhstan. This implies that an increase in the exchange rate may likely promote the growth of the AOECs' manufacturing sectors. The transmission mechanism through which this occurs might not be unconnected to the fact that a rise in the exchange rate discourages importation of manufacturing competitive goods. This in turn will most likely promote the growth of the manufacturing sector. A currency devaluation policy complemented by provision of adequate incentives to promote the domestic manufacturing output is recommended.

We can also conclude that the level of investment in the manufacturing sector of the AOECs is grossly inadequate. This implies that the manufacturing sectors of the A0ECs are suffering from inadequate capital. As shown in the discussion of the literature, the more capital intensive the manufacturing sector is, the stronger is its resistance to negative influence from the oil sector. This dearth in investment in the manufacturing sector of the AOECs is further revealed through the observation that electricity generation does not have any significant impact on manufacturing sector growth. Consequently, our study supports the call for aggressive 
investment policy that will accelerate a massive investment in the manufacturing sector of the AOECs.

Finally, it is apparent that there is a problem with the manufacturing sector of the A0ECs, and there is a need to address this problem if the growth of these countries is to be enhanced. Generally, any of the following courses of action can be employed to address these problems: (i) diversification; (ii) currency devaluation with adequate incentives to promote domestic manufacturing output; (iii) aggressive investment policy to increase capital formation in the A0ECs' manufacturing sector; (iv) stabilisation of the oil sector and utilisation of the oil revenue for more investment in the manufacturing sector; and (v) political will to carry out all these necessary measures. It should be noted that none of these measures is on its own a panacea for the problem of the AOECs' manufacturing sectors. All these efforts can be launched together or implemented in successive stages until the growth of the manufacturing sector is promoted.

\section{LIST OF REFERENCES}

Acosta, P. Lartey, E. \& Mandelman, F. (2009). Remittances and the Dutch disease. Journal of International Economics, 79, pp. 102-116.

Alawad, M. (2010). The Role of Manufacturing in Promoting Sustainable Economic Growth in the GCC. Institute of Social and Economic Research (Working Paper No. 24).

Arellano, M. \& Bond, S. (1991). Some tests of specification for panel data: Monte Carlo evidence and an application to employment equations. Review of Economic Studies, 58, pp. 277-297.

Anderson, T. \& Hsiao, C. (1982). Formulation and estimation of dynamic models using panel data. Journal of Econometrics, 18, pp. 47-82.

Alege, P. (2009). A Business Cycle Model for Nigeria. A Paper for Presentation at the African Econometric Society Conference, Abuja, Nigeria.

Alexey, K. (2011). Dutch Disease and Monetary Policy in Dil-Exporting Economy. Masters Dissertation, Department of Economics, Budapest, Hungary: Central European University.

Amuzegar, (2001). OPEC as Omen. Foreign Affairs, 77(6), p. 95.

Enoma, A \& Isedu, M. (2011). Impact of financial sector reforms on non-oil export in Nigeria. Journal of Economics, 2(2), pp. 115-120.

Auty, R.M. \& Evia, J.L. (2001). A Growth Collapse with Point Resources in Bolivia. In Auty, R.M. (ed.)

Resource Abundance and Economic Development. Oxford: Oxford University Press.

Barro, R. \& Lee, J. (1993). International comparisons of educational attainment. Journal of Monetary Economics, 32(3), pp. 363-394.

Beblawi, H \& Giacomo L. (1987). The Rentier State. New York: Croom Helm.

Bouakez, H., Rebei, N. \& Vencatachellum, D. (2008). Optimal Pass-Through of Oil Prices in an Economy with Nominal Rigidities. (Working Paper 08/31, CIRPEE).

Blanchard, 0. \& Gali, J. (2007). The macroeconomic effects of oil price shocks: Why are the 2000 s so different from the 1970s? National Bureau of Economic Research Working Paper No. 13368.

Blundell, R. \& Bond, S. (1998). Initial conditions and moment restrictions in dynamic panel data models. Journal of Econometrics, 87, pp. 115-143. 
Bulmer-Thomas, V. (1994). The Economic History of Latin America since Independence. Cambridge: Cambridge University Press.

Central Bank of Nigeria (CBN). (2010). Statistical Bulletin 2010 edition. Abuja, Nigeria: CBN.

Cimadomo, J. (2002). The Effects of Systematic Monetary Policy on Sectors: Factor model Analysis. Ecares Seminar Paper CP 114.

Cipolini, A., Hall, S. \& Nixon, J. (2011). The Inter-relationship between Monetary Policy and Endogenous Technical Progress. Bank of England Discussion Paper No. DP 11-99.

Corden, W. \& Neary, J. (1982). Booming sector and de-industrialisation in a small open economy. Economic Journal, 92, pp. 825-848.

Christiano, L.J. \& Eichenbaum, M. (1992). Current real business cycle theories and aggregate labour market fluctuations. American Economic Review, 82, pp. 430-450.

Delong, B.J. \& Summers, L.H. (1992). Macroeconomic Policy and Long-Run Growth. Federal Reserve Bank of Kansas City Quarterly Review, Fourth Quarter, pp. 5-29.

Dib, A. (2006). Nominal rigidities and monetary policy in Canada. Journal of Macroeconomics, 28, pp. 303-325.

Dickey, D.A., \& Fuller, W.A. (1979). Distribution of the Estimator for Autoregressive Time Series with a Unit root. Journal of the American Statistical Association, 74, pp. 427-431.

Égert, B. \& Leonard, C.S. (2007). Dutch disease scare in Kazakhstan: Is it real? William Davidson Institute. (Working paper no. 866).

Fedderke, J. (2003). Economic Growth: Theory and Evidence. Cape Town: University of Cape Town Press.

Franz, દ. (2009) Dynamic panel data methods for cross-section panels. University of Vienna press

Ghalayini, L. (2011). The Interaction between Oil Price and Economic Growth. Middle Eastern Finance and Economics, Issue 13.

Gujarati, S.N. (2007). Basic Econometrics. Singapore: McGraw-Hill.

Gylfason, T. (2001). Natural resources, education, and economic development. European Economic Review, 45, pp. 847-859.

Hauser C. (2010) Social Capital Formation and Intra-familial Correlation: A Social Panel Perspective Singapore Economic Review, 54(3), pp. 473-488.

International Monetary Fund (IMF). (2010). Economic Report (2010). Washington, D.C.: IMF. International Monetary Fund (IMF). (2008). Economic Report (2008). Washington, D.C.: IMF. International Monetary Fund (IMF). (2005). Economic Report (2005). Washington, D.C.: IMF. Ismail, K. (2010). The structural manifestation of the 'Dutch Disease': The case of oil exporting countries. IMF. (Working paper no. 103).

Jabber, P. (1997) Political and Economic Reform in the Muslim World. New York: Globicom Inc.

Karl, T. (1997). The Paradox of Plenty: Oil Booms and Petro-states. Berkeley and Los Angeles: University of California Press.

Kayode, A. (2000). Basic economic issues on Nigeria. Central Bank of Nigeria (CBN) Economic Review, 23, pp. 233-235. 
Lay, J. \& Mahmoud, T.0. (2005). The Resource Curse at Work: A Cross-Country Perspective with a Focus on Africa. In M. Basedau \& A. Mehler, (eds.) Resource Politics in sub-Saharan Africa. Hamburg: Hamburg African Studies/Etudes Africaines Hambourgeoises No. 14.

League of Arab States Reports. (2009). Arab Economic and Social Development summits. Kuwait Majid, A. (2008). The Contribution of the Oil Sector to Arab Economic Development. OFID Pamphlet Series. Vienna, Austria: OPEC Fund for Industrial Development.

Gertler, M. \& Karadi, P. (2011). A model of unconventional monetary policy. Journal of Monetary Economics, 58, pp. 17-34.

Mehrabadi, M., Nabiuny, E. \& Moghadam, H. (2012). Survey of oil and non-oil export effects on economic growth in Iran. Greener Journal of Economics and Accountancy, 1(1), pp. 8-18.

Mehrara, M., Sadr, M. \& Farahani, S. (2008). Threshold effects in the relationship between oil revenues and growth in oil exporting countries. Proceedings of Annual London Conference on Money, Economy and Management, 3-4 July, Imperial College, London.

Nigeria Village Square NVS report 2009. Viewpoints and articles compilation 2009

OPEC Fund for Industrial Development (OFID). (2006). Annual report 2006.

Oladipo, S. \& Fabayo, J. (2012). Global recession, oil sector and economic growth in Nigeria. Asian Transactions on Basic and Applied Sciences, 1(6), pp. 29-41.

Olatiwola, K. \& Okodua, H. (2009). Foreign Direct Investment, Non-Oil Exports, and Economic Growth in Nigeria: A Causality Analysis. Ota, Nigeria: Covenant University.

Olomola, P. (2007). Oil wealth and economic growth in African oil exporting countries. African Economic Research Consortium (AERC), Nairobi. (AERC research paper no. 170).

Torres-Reyna, 0. (2010). Panel data analysis fixed and random effects. Princeton: Princeton University press.

Penn World Table (PWT) 6.1

Roodman, D. (2006). How to do xtabond2: An introduction to "difference" and "system" GMM in stata. Centre for Global Development. (Working paper no. 103).

Sachs, J. \& Warner, A. (1995). Natural resource abundance and economic growth. National Bureau of Economic Research (NBER), Cambridge, MA. (NBER working paper no. 5398).

Sbordone, A.M., Tambalotti, A., Rao, K. \& Walsh, K. (2010). Policy Analysis Using DSGE Models: An Introduction. FRBNY Economic Policy Review, October.

Stauffer, M.E. (1984). xtivreg2: Stata module to perform extended IV/2SLS, GMM and AC/HAC, LIML and $k$-class regression for panel data models. [Online] Available:

http://ideas.repec.org/c/boc/bocode/s456501.html. (Accessed 22 November 2012).

World Industrial Development and Economic Research (WIDER). (2004). Economic Report on Africa's Developing Countries.

World Bank. (2004). World Development Indicators. Washington DC: World Bank. [Online] Available: http://data.worldbank.org/data-catalog/world-development-indicators World Bank Tables 2012 edition. (Accessed 18 March 2013). 